\title{
Worker compensation injuries among the Aboriginal population of British Columbia, Canada: incidence, annual trends, and ecological analysis of risk markers, 1987-2010
}

\author{
Andrew Jin ${ }^{1}$, M Anne George ${ }^{2^{*}}$, Mariana Brussoni ${ }^{3}$ and Christopher E Lalonde ${ }^{4}$
}

\begin{abstract}
Background: Aboriginal people in British Columbia $(\mathrm{BC})$ have higher injury incidence than the general population, but information is scarce regarding variability among injury categories, time periods, and geographic, demographic and socio-economic groups. Our project helps fill these gaps. This report focuses on workplace injuries.

Methods: We used BC's universal health care insurance plan as a population registry, linked to worker compensation and vital statistics databases. We identified Aboriginal people by insurance premium group and birth and death record notations. We identified residents of specific Aboriginal communities by postal code. We calculated crude incidence rate and Standardized Relative Risk (SRR) of worker compensation injury, adjusted for age, gender and Health Service Delivery Area (HSDA), relative to the total population of BC. We assessed annual trend by regressing SRR as a linear function of year. We tested hypothesized associations of geographic, socio-economic, and employment-related characteristics of Aboriginal communities with community SRR of injury by multivariable linear regression.
\end{abstract}

Results: During the period 1987-2010, the crude rate of worker compensation injury in BC was 146.6 per 10,000 person-years (95\% confidence interval: 146.4 to 146.9 per 10,000). The Aboriginal rate was 115.6 per 10,000 (95\% Cl: 114.4 to 116.8 per 10,000) and SRR was 0.88 ( $95 \%$ Cl: 0.87 to 0.89). Among those living on reserves SRR was 0.79 ( $95 \%$ Cl: 0.78 to 0.80 ). HSDA SRRs were highly variable, within both total and Aboriginal populations. Aboriginal males under 35 and females under 40 years of age had lower SRRs, but older Aboriginal females had higher SRRs. SRRs are declining, but more slowly for the Aboriginal population. The Aboriginal population was initially at lower risk than the total population, but parity was reached in 2006. These community characteristics independently predicted injury risk: crowded housing, proportion of population who identified as Aboriginal, and interactions between employment rate and income, occupational risk, proportion of university-educated persons, and year.

Conclusions: As employment rates rise, so has risk of workplace injury among the Aboriginal population. We need culturally sensitive prevention programs, targeting regions and industries where Aboriginal workers are concentrated and demographic groups that are at higher risk.

Keywords: Occupational injuries (MeSH), Workers' compensation (MeSH), Indians, North American (MeSH), Indigenous population (MeSH), "First Nations", British Columbia (MeSH), Canada (MeSH), Epidemiology (MeSH), Population surveillance (MeSH), Socioeconomic factors (MeSH)

\footnotetext{
* Correspondence: ageorge@cw.bc.ca

${ }^{2}$ University of British Columbia and Child \& Family Research Institute, University of Northern BC, Room 9-387, 3333 University Way, Prince George, BC V2N 3Z9, Canada

Full list of author information is available at the end of the article
} 


\section{Background}

Aboriginal people in British Columbia (BC) have higher incidences of severe injuries (as recorded in the BC Trauma Registry) [1] or death due to injury [2-6] than the general population. However, the absolute numbers of deaths and trauma-team cases occurring among Aboriginal people in the province are small, limiting ability to break down results and make meaningful comparisons between subpopulations. This can lead to over-generalization of findings and stigmatization of Aboriginal British Columbians as a group [1]. Also, within the Aboriginal population, limited information about variability in incidence rates among injury categories, geographic regions, and demographic and socio-economic groups hampers efforts to identify risk factors and develop targeted prevention programs. The project Injury in British Columbia's Aboriginal Communities: Building Capacity while Developing Knowledge [7] seeks to overcome these limitations by studying a broader range of injury morbidity events.

This report focuses on injuries claimed for worker compensation. Previous researchers in Canada have measured the incidence of worker compensation injuries among the general populations of the provinces of Ontario $[8,9]$ and $\mathrm{BC}[10]$, using population-based registries [8-10] or longitudinal cohort methods [9]. Another study measured incidence, among workers in $\mathrm{BC}$ employed in a specific industry, by linking employment records with the injury registry [11]. The population-based studies described variations of incidence rates by gender, age, time period, and geographic location, but study of other risk markers is difficult because such information is not usually available for both individual members of the population base and individuals recorded in the injury registry. The ecological approach, where the unit of observation is a geographic unit, can help overcome this limitation, because both injury incidence, and a broad range of socio-economic, geographic, and employment-related markers can be measured at the level of the geographic unit. A previous ecologic study of predictors of risk of worker compensation injury did this among 46 regions of Ontario [12].

This report describes incidence rates, annual trends, and predictors of risk of worker compensation injury among the Aboriginal population of BC. We found no previously published report on these topics regarding the Aboriginal population of any province of Canada. We consider such information to be important to broaden the understanding of both the health status of Aboriginal British Columbians and their participation in the economic life of the province.

\section{Methods}

Ethics review and permission for data access

The University of British Columbia Behavioural Research Ethics Board reviewed and approved our methods. Data
Stewards representing the BC Ministry of Health Services and Work Safe BC approved the data access requests. Population Data BC linked the data files and made the client records anonymous, before our analysis.

\section{Population counts}

We obtained one-day extracts of the consolidated registration and premium billing files of the Medical Services Plan of BC (MSP, the province's universal health care insurance program), at the mid-point of each fiscal year, 1985-1986 through 2010-2011. We took these to represent the total resident population of $\mathrm{BC}$. Within this population, we marked as "Aboriginal" any person with:

a) Membership in MSP Premium Group 21 (indicating insurance premiums paid by First Nations and Inuit Health Program, Health Canada, for reason of Aboriginal status), OR

b) One or both parents with Aboriginal status or resident on an Indian Reserve, as indicated on the Vital Statistics birth record, OR

c) Aboriginal status or resident of an Indian Reserve, as indicated on the Vital Statistics death record).

For purposes of ecologic analysis (see below), within the population we identified Aboriginal "communities". In BC there are 199 First Nations and Indian Bands recognized by and registered with the government of Canada. More than 1,000 parcels of land in BC have been designated as "reserves", each set apart for the collective use and benefit of the members of a specified First Nation or Indian Band. Some 498 of these reserves are currently inhabited. Approximately $44 \%$ of the Aboriginal people in $\mathrm{BC}$ reside on a reserve ("on-reserve") and $56 \%$ do not reside on a reserve ("off-reserve"). Conceptually, we defined a community as all the Aboriginal people residing on the reserves of one band. Operationally, we delineated each community by aggregating the postal codes of the reserves belonging to a band, and we assigned Aboriginal people to the community according to their postal code of residence. By this method, we identified 177 Aboriginal communities in BC. In fiscal year 2006-2007, total population of the communities was 62,059 and mean population per community was 351, with standard deviation of 419 . The number of communities is fewer than the number of bands, because in rural areas, due to low population density, full 6-digit postal codes correspond to large areas, containing both reserves and non-reserve areas, and sometimes containing the reserves of more than one band. Thus, in practice, the identified Aboriginal communities include both Aboriginal reserve residents and off-reserve Aboriginal persons living near by, and some communities contain more than one band. Although this does not perfectly match our 
conceptual definition, it suffices, because it is consistent with our underlying intention, which is to identify culturally homogenous clusters of Aboriginal people living in close proximity to one another.

We aggregated the 177 identified Aboriginal communities to create a subcategory of the Aboriginal population which we called "reserve". We classified all other Aboriginal persons as "not reserve".

There are sixteen Health Service Delivery Areas (HSDAs) in BC. The 2011 Census of Canada found that $62.3 \%$ of the population of $\mathrm{BC}$ resided in urban centres with populations greater than 100,000. If more than $62.3 \%$ of the 2011 population of an HSDA resided in such an urban centre then we classified the entire HSDA (and all its residents) as "urban" [13]. In this way we classified as urban six HSDAs containing $62.7 \%$ of the 2011 population of the province [14]: HSDAs 22 (Fraser North), 23 (Fraser South), 31 (Richmond), 32 (Vancouver), 33 (North Shore/Coast Garibaldi), and 41 (South Vancouver Island). Within these six HSDAs, $88.8 \%$ of the population resided in urban centres with populations greater than 100,000. We classified all other HSDAs (and their residents) as "not urban". Within these ten HSDAs, $17.8 \%$ of the population resided in urban centres with populations greater than 100,000. Figure 1 is a map of BC showing the 16 HSDAs in the province. The six urban HSDAs are marked with the symbol.

We tabulated population counts by fiscal year, gender, 5 -year age group, Aboriginal status, community, reserve residence, HSDA, and urban residence.

\section{Worker compensation injuries}

We tabulated counts of worker compensation injuries among residents of $\mathrm{BC}$, occurring from January 1, 1987 through December 31, 2010. We defined "worker compensation injury" as an injury registered for a claim with Work Safe BC (the province's workplace injury compensation program), with an ICD-9 numeric code diagnosis in the range 800 through 999. This definition excludes some chronic conditions recognized as injuries by Work Safe $\mathrm{BC}$, for example, tendonitis, carpal tunnel syndrome, noise-induced hearing loss, occupational lung diseases, and occupational cancers. Work Safe BC provides compensation for injury or disease that arises out of and in the course of employment, or is due to the nature of employment. Employers are required by law to register with Work Safe BC to provide coverage to their employees. Aboriginal subsistence activities (e.g., hunting, fishing, trapping, gathering wild plants, cutting trees) may be covered, if the individual registers with Work Safe BC and pays insurance premiums for the optional personal protection available to self-employed persons. In Canada, Aboriginal subsistence includes a right to earn a moderate living by selling the products of one's labour. Unpaid domestic labour is not considered employment. Injury occurring while travelling between one's place of residence and place of employment does not meet the test of "arising out of and in the course of employment, or due to the nature of employment". Full-time or part-time labour does not influence acceptance of an injury claim, though it does influence the amount of compensation.

We classified worker compensation injuries by injury type (trauma, poisoning, burn or other) using ranges of the ICD-9 numeric code diagnosis. We tabulated counts of injuries by injury type, calendar year (of injury occurrence), gender, 5-year age group, Aboriginal status, reserve residence, HSDA, and urban residence.

\section{Incidence rates of injury}

We calculated the crude rate of worker compensation injuries as the number of injuries divided by the personyears of observation (the sum of the annual population counts) during the same time period. We considered the crude rate to be a binomial proportion, and we estimated standard errors of the proportion, and 95\% confidence intervals of the proportion, using the method of Agresti and Coull [15]. Consistent with Statistics Canada policy $[16,17]$, we suppressed reporting of the crude rate in a cell if the coefficient of variation (the standard error of the crude rate divided by the crude rate) exceeded 0.333 .

We calculated rates of worker compensation injury using person-years of population as the denominator, because we consider such rates to be indicators of population health status (limited to one specific category of health outcome). Other researchers have used personyears of employment as the rate denominator, which would be appropriate if one thinks of injury risk in the manner of an insurer seeking to justify premiums levied on employers according to the size of the workforce. But that was not our intention. Also, our population counts are more reliable than estimates of numbers of employed persons derived from survey samples, which would also have had to be adjusted for intensity of employment (i.e., full-time or part-time employment) with even more propagation of random measurement error.

We calculated Standardized Relative Risk (SRR) of worker compensation injury relative to the risk of injury in the reference population $(95,457,166$ person-years, the combined total population of BC from January 1, 1987 through December 31, 2010) using the method of indirect standardization [18], adjusting for gender and age, or gender, age and HSDA, as appropriate for the intended comparisons. We suppressed reporting of the SRR in a cell if the coefficient of variation (the standard error of the expected number of injuries divided by the expected number) exceeded 0.333 .

The error bars in Figure 2 depict 95\% confidence intervals. Comparing two crude rates or two SRRs, we 


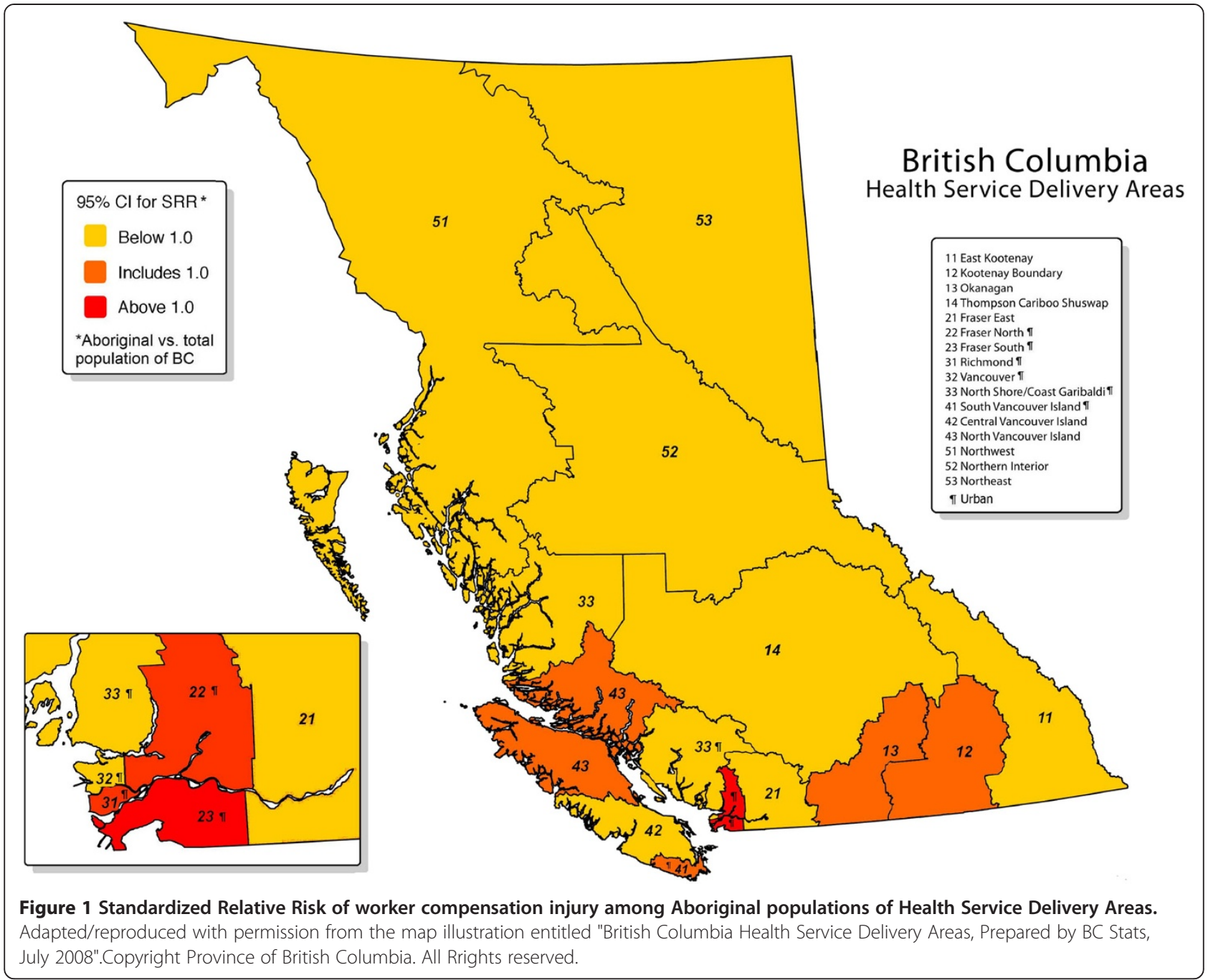

considered the difference to be "statistically significant" if the $95 \%$ confidence intervals did not overlap. This indicates $\mathrm{p}<0.006$, if the standard errors are equal, or $\mathrm{p}<0.021$ if one of the standard errors is up to five times larger than the other [19].

We assessed annual trend as a linear function with year as the independent variable, and SRR as the dependent variable. We considered the trend to be "statistically significant" if the 95\% confidence interval of the regression coefficient (the slope) did not include zero.

\section{Predictors of risk}

We expected that the individual-level analysis methods above would describe heterogeneity among age and gender groups, among geographic regions, among fiscal years of observation, between Aboriginal and non-Aboriginal, and between on-reserve Aboriginal and off-reserve Aboriginal populations, but would not explain why the heterogeneities exist. Therefore, to elucidate possible explanatory factors, we studied risk markers for worker compensation injury among the Aboriginal population using an ecological approach, where the unit of observation was the "community" (as defined above). As hypothesized risk factors, we selected socio-economic, housing, and geographic indicators that had previously been developed by Statistics Canada and Aboriginal Affairs and Northern Development Canada, which are used to allocate federal government resources to health care, education, housing, and economic development programs for Aboriginal people. We wanted to test if these markers had predictive validity with respect to risk of worker compensation injury, which is indicative of both health status and economic development.

Within communities, risk of injury among Aboriginal people is calculated using our own definition of "Aboriginal", derived from health insurance premium group and notations on birth and death records. However, every First Nation band makes its own residency rules, and not all residents of reserves would meet our definition of Aboriginal. We wanted to test if variability in the ethnic composition of reserve populations would introduce biases 


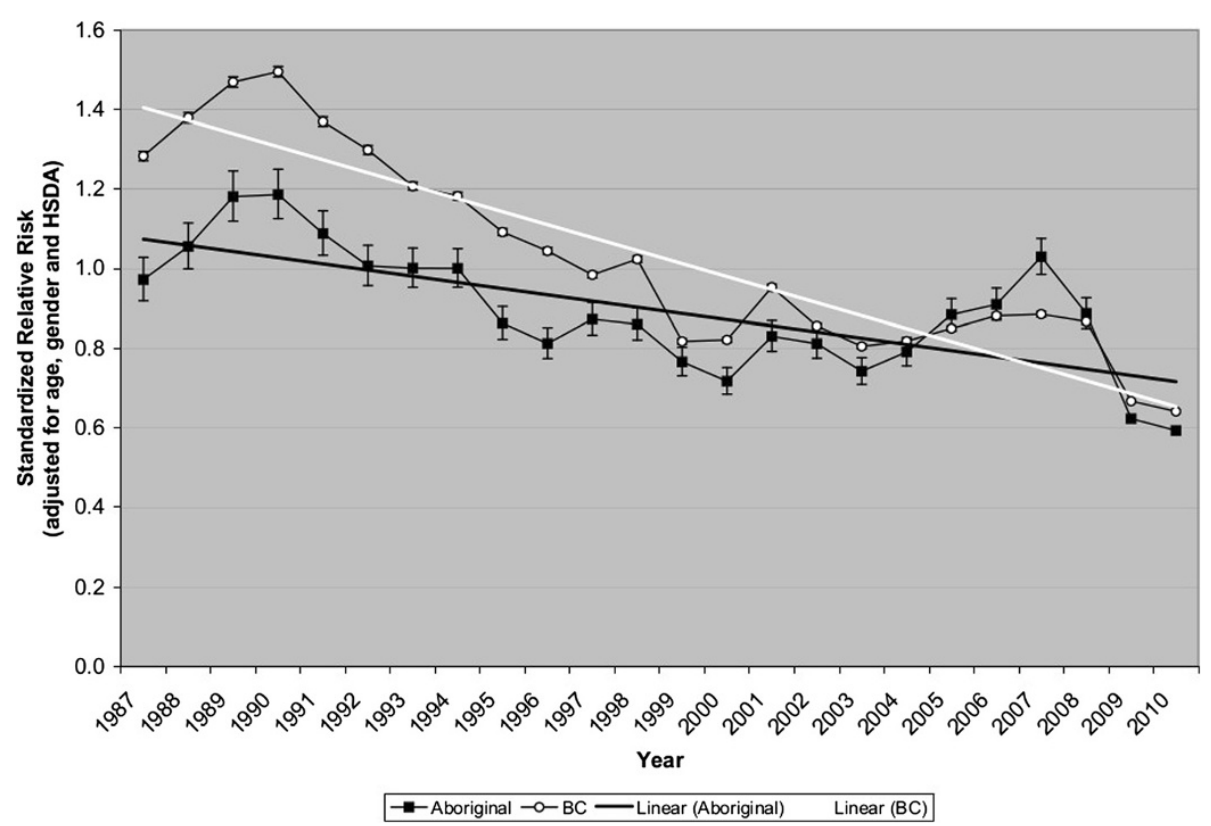

Figure 2 Worker compensation injuries, British Columbia, 1987-2010, Standardized Relative Risk by year.

into our ecologic analysis, and if so, to correct such biases. Therefore, we included in the analysis two Census-derived ecologic indicators describing ethnic composition.

From the 2001 and the 2006 Censuses of Canada we obtained customized data tabulations for all enumerated First Nation reserves, settlements or self-government districts in $\mathrm{BC}$, aggregated by First Nation band. The Census long-form (usually administered to a $20 \%$ sample of the population) was administered to $100 \%$ of residents of First Nation reserves, settlements and self-government districts. From these data, for as many communities as possible, we tabulated the following hypothesized socio-economic markers of injury risk:

- Total Income per capita,

- Community Well-Being Income Score [20], calculated as: $\log _{10}[($ Total Income per capita)/ 2000] / $\log _{10}[20] \times 100$,

- Proportion of population, age $25+$ years with at least a high school certificate,

- Proportion of population, age 25+ years with university degree, bachelors or higher,

- Average population per room (an index of the degree of crowding in the community's housing), calculated as the number of residents divided by the number of habitable rooms (not counting bathrooms, halls, vestibules and rooms used solely for business purposes) in the dwelling,

- Proportion of dwellings in need of major repairs (defective plumbing or electrical wiring, structural repairs to walls, floors or ceilings, etc., does not include desirable remodelling or additions),

- Proportion of population, age 25+ years, in the labour force (in the week before the census, employed, temporarily absent, looking for work, or starting work within 4 weeks),

- Proportion of population, age 25+ years, employed (any work for pay or self-employment in the week before the census),

- Proportion of population who identified themselves as "an Aboriginal person, that is, North American Indian, Métis or Inuit (Eskimo)",

- Proportion of population who gave only one response to the ethnic origin question, and it was a group that could be classified as North American Indian.

Some calculated proportions exceeded 100\% because Statistics Canada rounds cell counts to the nearest multiple of five, to protect privacy. If a community contained more than one First Nation band, then we calculated the community's marker as the population-weighted mean of the First Nation bands' markers. Statistics Canada reports only the total population count for aggregations with population less than 40, and suppresses income data for aggregations with population less than 250 . We were able to calculate the two income-related markers for 79 (of 177) communities in Census year 2001, and 73 communities in 2006. We were able to calculate the other markers listed above for 151 communities in 2001, and 127 communities in 2006. 
Rates of worker compensation claims differ among occupational [21] and industrial categories [22], and these factors (and size of payroll and previous claims experience) determine the insurance premiums that Work Safe $\mathrm{BC}$ levies upon employers. We hypothesized that the distribution of the community's labour force among occupational and industrial categories would help explain the community's risk of worker compensation injury. We invented two statistics that summarize the hypothesized hazardousness of the community's labour force distribution. Each statistic is the mean risk of work injury claim among the occupational or industrial categories in the total population of $\mathrm{BC}$, weighted by the number of persons in each occupational or industrial category in the community. Combining Work Safe BC injury claims statistics and Census data, we calculated the following work-related statistics of injury risk for each community:

- Risk of work injury claim, relative to the population of BC, expected from occupational categories [21], among labour force aged $15+$ years,

- Risk of work injury claim, relative to the population of BC, expected from industry categories [22], among labour force aged $15+$ years.

The Government of Canada's Department of Aboriginal Affairs and Northern Development has a classification system for calculating funding allocations to First Nation bands [23]. From this system, we assigned to communities the following hypothesized geographic markers of injury risk:

- Remoteness Index (higher score means more remote), and

- Environmental Index (higher score means more environmentally challenging).

These indices are numeric scores, based on geographic latitude, availability of year-round road access, and distance to the nearest "service centre" (a city or town having government services, banks and suppliers). If a community contained more than one First Nation band, then we calculated the community's index as the population-weighted mean of the bands' indices.

Worker compensation injury can only occur to employed people. It is plausible that risk factors for such injury would apply only to the fraction of the population who are employed. Therefore, for each of the above hypothesized socio-economic, work-related, and geographic risk markers we also created an employment-interaction variable, calculated as the risk marker multiplied by the proportion of the population in each community who were employed.

\section{Ecological analysis}

For each community, we calculated the age, gender and HSDA-adjusted SRR of worker compensation injury during the period 1999 through 2003 (a 5-year period centred about the Census year 2001) and during the period 2004 through 2008 (centred about the Census year 2006), relative to the total population of $\mathrm{BC}$ during the same time period. Logarithmic transformation approximately normalized the distribution of the SRRs (KolmogorovSmirnov statistic 0.058, Shapiro-Wilk statistic 0.988, $\mathrm{df}=319, \mathrm{p}=0.012$ ); therefore we used the natural logarithm of SRR as the dependent $(\mathrm{Y})$ variable for regression analysis.

We tested hypotheses of association by performing least-squares linear regressions. We tested census year, hypothesized socio-economic, work-related and geographic markers, and their employment-interaction variables, in turn as the single independent variable. Variables that had statistically significant association $(\mathrm{p}<0.05)$ with SRR of worker compensation injury in univariate analysis were included in subsequent multivariable regression analysis. We used stepwise backwards elimination of variables to arrive at the best-fitting multivariable model. At each step, the variable with the largest p-value was eliminated. Elimination stopped when all independent variables had regression coefficients significantly different from zero $(\mathrm{p}<0.05)$.

In the best-fitting model, " $\mathrm{B}$ " is the regression coefficient of each independent variable, representing the change in the dependent variable Ln (SRR) that is associated with a unit change in the independent variable. The relative risk associated with a one standard deviation change (SD) in the independent variable is calculated as the antilogarithm of BxSD. Repeating the calculation with the lower and upper $95 \%$ confidence limits of B gives the confidence limits of the relative risk.

\section{Results}

\section{Aboriginal status and reserve residence}

Table 1 shows crude rates and SRRs of injuries claimed for worker compensation, during the period 1987-2010, among the total population of $\mathrm{BC}$, the Aboriginal population, the Aboriginal population residing on reserve, and the Aboriginal population residing off-reserve. Table 1 also separates injuries into broad ranges of the ICD-9 numeric classification: trauma, poisoning, burn, and other. Because $96 \%$ of worker compensation injuries are in the category of trauma, we combined all injury categories for the remainder of the description and analysis.

Table 1 shows a pattern of the lowest incidence among the Aboriginal population on or near a reserve, higher incidence among the Aboriginal population off-reserve, and highest incidence in the total population of $\mathrm{BC}$. Standardization by age, gender and HSDA reduces but does not eliminate the disparities among the three population groups. In particular, the gap between the offreserve Aboriginal population and the total population 
Table 1 Worker compensation injuries [1], British Columbia, 1987-2010 [2]

\begin{tabular}{|c|c|c|c|c|c|c|c|c|c|c|c|}
\hline $\begin{array}{l}\text { Injury Category [3] } \\
\mathrm{BC}\end{array}$ & P-years [4] & Obs [5] & Exp [6] & Rate [7] & \multicolumn{3}{|c|}{$95 \% \mathrm{Cl}$ for Rate } & SRR [8] & \multicolumn{3}{|c|}{ 95\% Cl for SRR } \\
\hline Total, All injuries & $95,457,166$ & $1,399,661$ & $1,399,659$ & 146.6 & 146.4 & to & 146.9 & 1.00 & 1.00 & to & 1.00 \\
\hline Trauma & $95,457,166$ & $1,343,044$ & $1,343,042$ & 140.7 & 140.5 & to & 140.9 & 1.00 & 1.00 & to & 1.00 \\
\hline Poisoning & $95,457,166$ & 6,469 & 6,469 & 0.7 & 0.7 & to & 0.7 & 1.00 & 0.98 & to & 1.02 \\
\hline Burn & $95,457,166$ & 45,612 & 45,612 & 4.8 & 4.7 & to & 4.8 & 1.00 & 0.99 & to & 1.01 \\
\hline . Other & $95,457,166$ & 4,536 & 4,536 & 0.5 & 0.5 & to & 0.5 & 1.00 & 0.97 & to & 1.03 \\
\hline \multicolumn{12}{|l|}{$\mathrm{BC}$, Aboriginal } \\
\hline Total, All injuries & $3,091,021$ & 35,736 & 40,608 & 115.6 & 114.4 & to & 116.8 & 0.88 & 0.87 & to & 0.89 \\
\hline Trauma & $3,091,021$ & 34,504 & 38,826 & 111.6 & 110.5 & to & 112.8 & 0.89 & 0.88 & to & 0.90 \\
\hline Poisoning & $3,091,021$ & 180 & 202 & 0.6 & 0.5 & to & 0.7 & 0.89 & 0.78 & to & 1.02 \\
\hline Burn & $3,091,021$ & 903 & 1,429 & 2.9 & 2.7 & to & 3.1 & 0.63 & 0.60 & to & 0.67 \\
\hline Other & $3,091,021$ & 149 & 151 & 0.5 & 0.4 & to & 0.6 & 0.99 & 0.84 & to & 1.16 \\
\hline \multicolumn{12}{|l|}{ BC, Aboriginal, off-reserve } \\
\hline Total, All injuries & $1,688,590$ & 20,983 & 21,898 & 124.3 & 124.3 & to & 122.6 & 0.96 & 0.95 & to & 0.97 \\
\hline Trauma & $1,688,590$ & 20,202 & 20,931 & 119.6 & 119.6 & to & 118.0 & 0.97 & 0.95 & to & 0.98 \\
\hline Poisoning & $1,688,590$ & 98 & 106 & 0.6 & 0.6 & to & 0.5 & 0.92 & 0.76 & to & 1.12 \\
\hline Burn & $1,688,590$ & 597 & 781 & 3.5 & 3.5 & to & 3.3 & 0.76 & 0.71 & to & 0.82 \\
\hline Other & $1,688,590$ & 86 & 79 & 0.5 & 0.5 & to & 0.4 & 1.08 & 0.87 & to & 1.35 \\
\hline \multicolumn{12}{|l|}{$\mathrm{BC}$, Aboriginal, on-reserve } \\
\hline Total, All injuries & $1,393,652$ & 14,641 & 18,595 & 105.1 & 105.1 & to & 103.4 & 0.79 & 0.78 & to & 0.80 \\
\hline Trauma & $1,393,652$ & 14,195 & 17,787 & 101.9 & 101.9 & to & 100.2 & 0.80 & 0.79 & to & 0.81 \\
\hline Poisoning & $1,393,652$ & 81 & 95 & 0.6 & 0.6 & to & 0.5 & 0.85 & 0.70 & to & 1.04 \\
\hline Burn & $1,393,652$ & 302 & 643 & 2.2 & 2.2 & to & 1.9 & 0.47 & 0.43 & to & 0.51 \\
\hline Other & $1,393,652$ & 63 & 71 & 0.5 & 0.5 & to & 0.4 & 0.89 & 0.70 & to & 1.13 \\
\hline
\end{tabular}

Notes:

1. "Injury" defined as Diagnosis in the range ICD9:800-999.

2. Injuries occurring during the observation period 1987-Jan-01 to 2010-Dec-31.

3. Injuries classified by ICD9 numeric code.

4. Person-years is the sum of annual population counts during the observation period.

5. Observed number of injuries.

6. Expected number, indirectly standardized, based on age, gender and HSDA-specific rates in the total population of BC.

7. Crude Rate per 10,000 person-years.

8. Standardized Relative Risk (compared to the total population of BC) $=$ Observed/Expected.

of $\mathrm{BC}$ (i.e., the reference population) is small, but remains statistically significant.

\section{HSDAs and urban residence}

Tables 2 and 3 show crude rates and age and genderadjusted SRRs of injuries claimed for worker compensation, during the period 1987-2010, within the total populations (Table 2) and the Aboriginal populations (Table 3) of the HSDAs. Depending on the HSDA, Aboriginal people may be at higher $(\mathrm{SRR}>1)$, lower $(\mathrm{SRR}<1)$, or the same risk (SRR $=1)$ of injury as the total population of the province (Figure 1). There are differences in risk of worker compensation injury between HSDAs, but these differences do not necessarily apply to both the Aboriginal and the total populations. For example, within the total population, the highest age- and gender-standardized risks of worker compensation injury occur in HSDAs 21, 22 and 23, but within the Aboriginal population, the highest risks occur in HSDAs 22, 23 and 31. Within the total population, urban and not urban residents had the same age- and gender-standardized risks of worker compensation injury, but within the Aboriginal population, urban residents had higher age- and gender-standardized risk of worker compensation injury (SRR $=0.95,95 \%$ confidence interval: 0.93 to 0.96 ) than those who were not urban $(\mathrm{SRR}=0.79,95 \% \mathrm{CI}: 0.78$ to 0.80 ). However, as shown in Table 3 and Figure 1, not all urban HSDAs showed above-average risks among their Aboriginal populations: HSDAs 22, 23 and 31 did (lower 95\% confidence limit of SRR was above one), but HSDAs 32 and 
Table 2 Worker compensation injuries [1], British Columbia, 1987-2010 [2], by Health Service Delivery Area

\begin{tabular}{|c|c|c|c|c|c|c|c|c|c|c|c|}
\hline \multirow{2}{*}{$\frac{\text { HSDA }}{11}$} & \multirow{2}{*}{$\frac{\text { P-years [3] }}{1,847,429}$} & \multirow{2}{*}{$\frac{\text { Obs [4] }}{22,605}$} & \multirow{2}{*}{$\begin{array}{l}\text { Exp [5] } \\
25,976\end{array}$} & \multirow{2}{*}{$\begin{array}{l}\text { Rate [6] } \\
122\end{array}$} & \multicolumn{3}{|c|}{ 95\% Cl for Rate } & \multirow{2}{*}{$\begin{array}{l}\text { SRR [7] } \\
0.87\end{array}$} & \multicolumn{3}{|c|}{$95 \% \mathrm{Cl}$ for SRR } \\
\hline & & & & & 121 & to & 124 & & 0.86 & to & 0.88 \\
\hline 12 & $1,878,968$ & 24,204 & 25,856 & 129 & 127 & to & 130 & 0.94 & 0.92 & to & 0.95 \\
\hline 13 & $7,129,280$ & 92,766 & 93,549 & 130 & 129 & to & 131 & 0.99 & 0.99 & to & 1.00 \\
\hline 14 & $4,987,600$ & 59,730 & 70,736 & 120 & 119 & to & 121 & 0.84 & 0.84 & to & 0.85 \\
\hline 21 & $5,455,829$ & 94,435 & 74,278 & 173 & 172 & to & 174 & 1.27 & 1.26 & to & 1.28 \\
\hline 22 & $11,998,748$ & 211,048 & 183,029 & 176 & 175 & to & 177 & 1.15 & 1.15 & to & 1.16 \\
\hline 23 & $13,344,187$ & 251,995 & 191,340 & 189 & 188 & to & 190 & 1.32 & 1.31 & to & 1.32 \\
\hline 31 & $3,979,078$ & 51,080 & 59,421 & 128 & 127 & to & 129 & 0.86 & 0.85 & to & 0.87 \\
\hline 32 & $13,897,287$ & 170,380 & 224,694 & 123 & 122 & to & 123 & 0.76 & 0.76 & to & 0.76 \\
\hline 33 & $6,104,957$ & 69,383 & 88,384 & 114 & 113 & to & 114 & 0.79 & 0.78 & to & 0.79 \\
\hline 41 & $7,873,455$ & 104,328 & 109,547 & 133 & 132 & to & 133 & 0.95 & 0.95 & to & 0.96 \\
\hline 42 & $5,507,969$ & 77,846 & 73,643 & 141 & 140 & to & 142 & 1.06 & 1.05 & to & 1.06 \\
\hline 43 & $2,656,173$ & 42,981 & 37,237 & 162 & 160 & to & 163 & 1.15 & 1.14 & to & 1.17 \\
\hline 51 & $2,034,014$ & 28,103 & 30,192 & 138 & 137 & to & 140 & 0.93 & 0.92 & to & 0.94 \\
\hline 52 & $3,562,522$ & 44,853 & 53,539 & 126 & 125 & to & 127 & 0.84 & 0.83 & to & 0.84 \\
\hline 53 & $1,551,472$ & 17,162 & 23,369 & 111 & 109 & to & 112 & 0.73 & 0.73 & to & 0.74 \\
\hline Urban [8] & $57,197,712$ & 858,214 & 856,415 & 150 & 150 & to & 150 & 1.00 & 1.00 & to & 1.00 \\
\hline Not [9] & $36,611,256$ & 504,685 & 508,375 & 138 & 137 & to & 138 & 0.99 & 0.99 & to & 1.00 \\
\hline
\end{tabular}

1. "Injury" defined as any diagnosis in the range ICD9:800-999

2. Injuries occurring during the observation period 1987-Jan-01 to 2010-Dec-31.

3. Person-years is the sum of annual population counts during the observation period.

4. Observed number of injuries.

5. Expected number, indirectly standardized, based on age- and gender-specific rates in total population of BC

6. Crude Rate per 10,000 person-years.

7. Standardized Relative Risk (compared to the total population of $B C$ ) $=$ Observed/Expected.

8. Urban: aggregation of HSDAs $22,23,31,32,33$ and 41 , where $>62.3 \%$ of the HSDA population live in a large population centre.

9. Not urban: aggregation of HSDAs $11,12,13,14,21,42,43,51,52,53$.

33 clearly did not (upper $95 \%$ confidence limit of SRR was below one).

\section{Age and gender}

Tables 4 and 5 show crude rates and SRRs of injuries claimed for worker compensation, among the total population (Table 4) and the Aboriginal population (Table 5) of $\mathrm{BC}$, by age and gender categories. Crude rates (age- and gender-specific) of worker compensation injury are higher among males than among females in all age groups. Among males, injury rates are highest among men aged 20 to 29 years, and decline steadily as age increases. Among females, worker compensation injury rates are highest among women aged 40 to 54 years.

SRRs (adjusted for age, gender and HSDA) show that younger Aboriginal persons (males under 35 years and females under 40 years of age) have lower risk of worker compensation injury compared to persons of the same age and gender in the total population. Older Aboriginal males have about the same risk of worker compensation injury as males in the total population. Older Aboriginal females have higher risk of worker compensation injury than females in the total population.

\section{Annual trends}

Tables 6 and 7 show crude rates and SRRs of injuries claimed for worker compensation, during the period 1987-2010, among the total population (Table 6) and the Aboriginal population (Table 7), by year. Figure 2 depicts comparisons of SRRs between these populations, regarding all injuries combined. SRRs in both the tables and figures have been adjusted for age, gender, and HSDA. Recall that the reference population is the combined total population of $\mathrm{BC}$ during the entire period (1987 through 2010). Thus, the SRR for the total population of $\mathrm{BC}$ in a particular year can be higher or lower than one, but the average of the SRRs for the total population of $\mathrm{BC}$, over all the years, will be one.

SRR trends (Figure 2) show that risks of injury are declining, although the rate of decline has been greater for the total population (mean change in SRR was -0.033 per year, $95 \%$ confidence interval: -0.039 to -0.027 ) than 
Table 3 Worker compensation injuries [1], Aboriginal BC, 1987-2010 [2], by Health Service Delivery Area

\begin{tabular}{|c|c|c|c|c|c|c|c|c|c|c|c|}
\hline \multirow{2}{*}{$\frac{\text { HSDA }}{11}$} & \multirow{2}{*}{$\frac{\text { P-years [3] }}{38,313}$} & \multirow{2}{*}{$\frac{\text { Obs [4] }}{443}$} & \multirow{2}{*}{$\begin{array}{l}\text { Exp [5] } \\
512\end{array}$} & \multirow{2}{*}{$\begin{array}{l}\text { Rate [6] } \\
116\end{array}$} & \multicolumn{3}{|c|}{$95 \% \mathrm{Cl}$ for Rate } & \multirow{2}{*}{$\begin{array}{l}\text { SRR [7] } \\
0.87\end{array}$} & \multicolumn{3}{|c|}{ 95\% Cl for SRR } \\
\hline & & & & & 105 & to & 127 & & 0.79 & to & 0.94 \\
\hline 12 & 13,647 & 165 & 169 & 121 & 104 & to & 141 & 0.98 & 0.84 & to & 1.14 \\
\hline 13 & 161,664 & 2,177 & 2,184 & 135 & 129 & to & 140 & 1.00 & 0.96 & to & 1.04 \\
\hline 14 & 404,410 & 3,821 & 5,738 & 94 & 92 & to & 98 & 0.67 & 0.65 & to & 0.68 \\
\hline 21 & 196,605 & 2,393 & 2,612 & 122 & 117 & to & 127 & 0.92 & 0.88 & to & 0.95 \\
\hline 22 & 111,440 & 1,967 & 1,526 & 177 & 169 & to & 184 & 1.29 & 1.23 & to & 1.36 \\
\hline 23 & 122,044 & 1,927 & 1,437 & 158 & 151 & to & 165 & 1.34 & 1.27 & to & 1.41 \\
\hline 31 & 17,062 & 404 & 229 & 237 & 215 & to & 261 & 1.76 & 1.55 & to & 2.01 \\
\hline 32 & 261,269 & 2,916 & 4,152 & 112 & 108 & to & 116 & 0.70 & 0.68 & to & 0.72 \\
\hline 33 & 233,561 & 2,868 & 3,360 & 123 & 118 & to & 127 & 0.85 & 0.83 & to & 0.88 \\
\hline 41 & 156,312 & 2,090 & 2,160 & 134 & 128 & to & 140 & 0.97 & 0.93 & to & 1.01 \\
\hline 42 & 329,123 & 3,711 & 4,353 & 113 & 109 & to & 116 & 0.85 & 0.83 & to & 0.88 \\
\hline 43 & 157,943 & 2,108 & 2,130 & 133 & 128 & to & 139 & 0.99 & 0.95 & to & 1.03 \\
\hline 51 & 490,310 & 5,348 & 6,854 & 109 & 106 & to & 112 & 0.78 & 0.76 & to & 0.80 \\
\hline 52 & 275,145 & 2,279 & 3,706 & 83 & 80 & to & 86 & 0.61 & 0.60 & to & 0.63 \\
\hline 53 & 98,686 & 846 & 1,277 & 86 & 80 & to & 92 & 0.66 & 0.63 & to & 0.70 \\
\hline Urban [8] & 901,688 & 12,172 & 12,864 & 135 & 133 & to & 137 & 0.95 & 0.93 & to & 0.96 \\
\hline Not [9] & $2,165,846$ & 23,291 & 29,534 & 108 & 106 & to & 109 & 0.79 & 0.78 & to & 0.80 \\
\hline
\end{tabular}

Notes:

1. "Injury" defined as any diagnosis in the range ICD9:800-999.

2. Injuries occurring during the observation period 1987-Jan-01 to 2010-Dec-31.

3. Person-years is the sum of annual population counts during the observation period.

4. Observed number of injuries.

5. Expected number, indirectly standardized, based on age- and gender-specific rates in total population of BC.

6. Crude Rate per 10,000 person-years.

7. Standardized Relative Risk (compared to the total population of $\mathrm{BC}$ ) $=$ Observed/Expected

8. Urban: aggregation of HSDAs $22,23,31,32,33$ and 41 , where $>62.3 \%$ of the HSDA population live in a large population centre.

9. Not urban: aggregation of HSDAs $11,12,13,14,21,42,43,51,52,53$.

for the Aboriginal population (mean change in SRR was -0.016 per year, $95 \%$ CI: -0.022 to -0.009 ). The Aboriginal population was at lower risk than the total population at the start of the period (1987), but parity was reached (the trend lines converged) in 2006. The risk of worker compensation injury among the Aboriginal population increased during the years 2003 through 2007, then declined markedly.

\section{Ecological analysis of predictors of risk}

Our analysis of custom data from the Census showed that Aboriginal people residing on reserves have lower employment rates than the total population of $\mathrm{BC}$ ( $45.4 \%$ vs. $61.1 \%$ in 2001 , and $46.2 \%$ vs. $62.4 \%$ in 2006 ); on the other hand, when they are employed, they are more likely to work in hazardous occupations (expected relative risk of worker compensation claim, "RR" was 1.10 in 2001, increasing to 1.14 in 2006) or industries $(\mathrm{RR}=1.08$ in both 2001 and 2006). Compared to the male labour force of $\mathrm{BC}$, the Aboriginal male labour force residing on reserves are more concentrated in "trades, transport and equipment operators and related occupations", "occupations unique to primary industry", and "occupations unique to processing, manufacturing and utilities" (i.e., the proportion of the Aboriginal labour force in each of these categories was greater than the proportion of the $\mathrm{BC}$ general population labour force in the same category.) These are "blue-collar" occupational groups, with relatively higher rates of worker compensation claims [21]. The Aboriginal male labour force is also more concentrated in "occupations in social science, education, government service and religion." This is generally an occupational category with a low risk of worker compensation claim [21]. However, on Aboriginal reserves, operations of the band government represent a disproportionately large amount of economic activity, and "government service" may have a different meaning than elsewhere. Compared to the female labour force of $\mathrm{BC}$, the Aboriginal female labour force residing on reserves are more concentrated in the high-risk occupational categories of "trades, transport and equipment operators and related occupations", and "occupations unique to primary industry. The Aboriginal female labour force is also more concentrated in the medium-risk category of "sales and 
Table 4 Worker compensation injuries [1], British Columbia, 1987-2010 [2], by Age and Gender

\begin{tabular}{|c|c|c|c|c|c|c|c|c|c|c|c|c|}
\hline \multirow{2}{*}{$\frac{\text { Gender }}{F}$} & \multirow{2}{*}{$\frac{\text { Age }}{15-19}$} & \multirow{2}{*}{$\frac{\text { P-years [3] }}{3,091,296}$} & \multirow{2}{*}{$\begin{array}{l}\text { Obs [4] } \\
18,913\end{array}$} & \multirow{2}{*}{$\frac{\operatorname{Exp}[5]}{18,913}$} & \multirow{2}{*}{$\begin{array}{l}\text { Rate [6] } \\
61\end{array}$} & \multicolumn{3}{|c|}{$95 \% \mathrm{Cl}$ for Rate } & \multirow{2}{*}{$\begin{array}{l}\text { SRR [7] } \\
1.00\end{array}$} & \multicolumn{3}{|c|}{$95 \% \mathrm{Cl}$ for SRR } \\
\hline & & & & & & 60 & to & 62 & & 0.99 & to & 1.01 \\
\hline $\mathrm{F}$ & $20-24$ & $3,215,407$ & 39,379 & 39,379 & 122 & 121 & to & 124 & 1.00 & 0.99 & to & 1.01 \\
\hline$F$ & $25-29$ & $3,478,049$ & 42,537 & 42,537 & 122 & 121 & to & 123 & 1.00 & 0.99 & to & 1.01 \\
\hline $\mathrm{F}$ & $30-34$ & $3,702,923$ & 45,675 & 45,675 & 123 & 122 & to & 124 & 1.00 & 0.99 & to & 1.01 \\
\hline $\mathrm{F}$ & $35-39$ & $3,861,158$ & 50,660 & 50,660 & 131 & 130 & to & 132 & 1.00 & 0.99 & to & 1.01 \\
\hline$F$ & $40-44$ & $3,830,469$ & 53,141 & 53,141 & 139 & 138 & to & 140 & 1.00 & 0.99 & to & 1.01 \\
\hline$F$ & $45-49$ & $3,525,752$ & 50,340 & 50,340 & 143 & 142 & to & 144 & 1.00 & 0.99 & to & 1.01 \\
\hline$F$ & $50-54$ & $3,024,714$ & 40,801 & 40,801 & 135 & 134 & to & 136 & 1.00 & 0.99 & to & 1.01 \\
\hline$F$ & $55-59$ & $2,558,851$ & 26,963 & 26,963 & 105 & 104 & to & 107 & 1.00 & 0.99 & to & 1.01 \\
\hline$F$ & $60-64$ & $2,186,965$ & 11,050 & 11,050 & 51 & 50 & to & 51 & 1.00 & 0.98 & to & 1.02 \\
\hline$F$ & $65-69$ & $1,912,893$ & 1,279 & 1,279 & 7 & 6 & to & 7 & 1.00 & 0.95 & to & 1.06 \\
\hline$F$ & $70-74$ & $1,670,886$ & 225 & 225 & 1 & 1 & to & 2 & 1.00 & 0.88 & to & 1.14 \\
\hline M & $15-19$ & $3,256,059$ & 51,250 & 51,250 & 157 & 156 & to & 159 & 1.00 & 0.99 & to & 1.01 \\
\hline M & $20-24$ & $3,186,968$ & 137,742 & 137,742 & 432 & 430 & to & 434 & 1.00 & 0.99 & to & 1.01 \\
\hline M & $25-29$ & $3,377,301$ & 154,893 & 154,893 & 459 & 456 & to & 461 & 1.00 & 1.00 & to & 1.00 \\
\hline M & $30-34$ & $3,611,964$ & 155,457 & 155,457 & 430 & 428 & to & 432 & 1.00 & 1.00 & to & 1.00 \\
\hline M & $35-39$ & $3,797,595$ & 142,295 & 142,295 & 375 & 373 & to & 377 & 1.00 & 0.99 & to & 1.01 \\
\hline M & $40-44$ & $3,806,541$ & 122,056 & 122,056 & 321 & 319 & to & 322 & 1.00 & 0.99 & to & 1.01 \\
\hline M & $45-49$ & $3,542,795$ & 97,188 & 97,188 & 274 & 273 & to & 276 & 1.00 & 0.99 & to & 1.01 \\
\hline M & $50-54$ & $3,056,634$ & 73,977 & 73,977 & 242 & 240 & to & 244 & 1.00 & 0.99 & to & 1.01 \\
\hline M & $55-59$ & $2,591,967$ & 51,784 & 51,784 & 200 & 198 & to & 201 & 1.00 & 0.99 & to & 1.01 \\
\hline M & $60-64$ & $2,179,698$ & 25,923 & 25,923 & 119 & 117 & to & 120 & 1.00 & 0.99 & to & 1.01 \\
\hline M & $65-69$ & $1,821,029$ & 4,182 & 4,182 & 23 & 22 & to & 24 & 1.00 & 0.97 & to & 1.03 \\
\hline M & $70-74$ & $1,479,753$ & 1,024 & 1,024 & 7 & 7 & to & 7 & 1.00 & 0.94 & to & 1.06 \\
\hline
\end{tabular}

Notes:

1. "Injury" defined as any diagnosis in the range ICD9:800-999.

2. Injuries occurring during the observation period 1987-Jan-01 to 2010-Dec-31.

3. Person-years is the sum of annual population counts during the observation period

4. Observed number of injuries.

5. Expected number, indirectly standardized, based on age, gender and HSDA-specific rates in total population of BC.

6. Crude Rate per 10,000 person-years.

7. Standardized Relative Risk (compared to the total population of $B C$ ) $=$ Observed/Expected

service occupations". Like Aboriginal males, the Aboriginal female labour force is more concentrated in the generally low-risk category of "occupations in social science, education, government service and religion." By industry category, the Aboriginal male labour force is more concentrated in "agriculture, forestry, fishing and hunting", "construction" and "manufacturing". These are industries with relatively higher rates of worker compensation claims. The Aboriginal male labour force is also more concentrated in "mining and oil and gas extraction" (medium-risk), and "public administration", and industry with a relatively low rate of worker compensation claims [22]. Again, on Aboriginal reserves, operations of the band government represent a disproportionately large amount of economic activity, and "public administration" may have a different meaning than elsewhere. The Aboriginal female labour force is more concentrated in the high-risk industrial categories of "agriculture, forestry, fishing and hunting", and "construction". The Aboriginal female labour force is also more concentrated in "mining and oil and gas extraction" (medium-risk), and "public administration", and industry with a relatively low rate of worker compensation claims [22].

Tables 8 and 9 show regression statistics from the preliminary regression models with a single independent $(\mathrm{X})$ variable. "P" is the probability of the null hypothesis that $\mathrm{R}^{2}$ is equal to zero. If "P" was less than 0.05 , then the independent variable was retained for subsequent multivariable regression analysis.

Table 10 shows regression statistics from the best-fitting regression model with multiple independent $(\mathrm{X})$ variables. The best-fitting model identified the following as statistically significant predictors of worker compensation injury 
Table 5 Worker compensation injuries [1], Aboriginal BC, 1987-2010 [2], by Age and Gender

\begin{tabular}{|c|c|c|c|c|c|c|c|c|c|c|c|c|}
\hline \multirow{2}{*}{$\frac{\text { Gender }}{F}$} & \multirow{2}{*}{$\begin{array}{l}\text { Age } \\
15-19\end{array}$} & \multirow{2}{*}{$\begin{array}{l}\text { P-years [3] } \\
135,848\end{array}$} & \multirow{2}{*}{$\begin{array}{l}\text { Obs [4] } \\
385\end{array}$} & \multirow{2}{*}{$\begin{array}{l}\text { Exp [5] } \\
790\end{array}$} & \multirow{2}{*}{$\begin{array}{l}\text { Rate [6] } \\
28\end{array}$} & \multicolumn{3}{|c|}{$95 \% \mathrm{Cl}$ for Rate } & \multirow{2}{*}{$\begin{array}{l}\text { SRR [7] } \\
0.49\end{array}$} & \multicolumn{3}{|c|}{$95 \% \mathrm{Cl}$ for SRR } \\
\hline & & & & & & 26 & to & 31 & & 0.45 & to & 0.52 \\
\hline $\mathrm{F}$ & $20-24$ & 127,128 & 890 & 1,445 & 70 & 66 & to & 75 & 0.62 & 0.58 & to & 0.65 \\
\hline $\mathrm{F}$ & $25-29$ & 129,776 & 1,098 & 1,497 & 85 & 80 & to & 90 & 0.73 & 0.70 & to & 0.77 \\
\hline $\mathrm{F}$ & $30-34$ & 129,199 & 1,317 & 1,496 & 102 & 97 & to & 108 & 0.88 & 0.84 & to & 0.93 \\
\hline $\mathrm{F}$ & $35-39$ & 122,522 & 1,405 & 1,522 & 115 & 109 & to & 121 & 0.92 & 0.88 & to & 0.97 \\
\hline $\mathrm{F}$ & $40-44$ & 108,519 & 1,397 & 1,419 & 129 & 122 & to & 136 & 0.98 & 0.93 & to & 1.04 \\
\hline F & $45-49$ & 89,472 & 1,175 & 1,192 & 131 & 124 & to & 139 & 0.99 & 0.93 & to & 1.04 \\
\hline F & $50-54$ & 68,418 & 865 & 846 & 126 & 118 & to & 135 & 1.02 & 0.96 & to & 1.09 \\
\hline F & $55-59$ & 51,343 & 589 & 488 & 115 & 106 & to & 124 & 1.21 & 1.10 & to & 1.32 \\
\hline F & $60-64$ & 38,327 & 226 & 176 & 59 & 52 & to & 67 & 1.28 & 1.11 & to & 1.49 \\
\hline$F$ & $65-69$ & 27,860 & 29 & 20 & 10 & 7 & to & 15 & 1.45 & 0.93 & to & 2.28 \\
\hline$F$ & $70-74$ & 19,479 & 7 & 3 & 4 & 2 & to & 8 & 2.66 & 0.80 & to & 19.00 \\
\hline M & $15-19$ & 138,807 & 1,117 & 2,012 & 80 & 76 & to & 85 & 0.56 & 0.53 & to & 0.58 \\
\hline M & $20-24$ & 122,074 & 3,753 & 5,001 & 307 & 298 & to & 317 & 0.75 & 0.73 & to & 0.77 \\
\hline M & $25-29$ & 124,279 & 4,807 & 5,552 & 387 & 376 & to & 398 & 0.87 & 0.84 & to & 0.89 \\
\hline M & $30-34$ & 122,053 & 4,834 & 5,073 & 396 & 385 & to & 407 & 0.95 & 0.93 & to & 0.98 \\
\hline M & $35-39$ & 114,734 & 4,095 & 4,115 & 357 & 346 & to & 368 & 1.00 & 0.97 & to & 1.03 \\
\hline M & $40-44$ & 100,165 & 3,026 & 3,066 & 302 & 292 & to & 313 & 0.99 & 0.95 & to & 1.02 \\
\hline M & $45-49$ & 81,440 & 2,063 & 2,130 & 253 & 243 & to & 264 & 0.97 & 0.93 & to & 1.01 \\
\hline M & $50-54$ & 61,645 & 1,416 & 1,412 & 230 & 218 & to & 242 & 1.00 & 0.95 & to & 1.06 \\
\hline M & $55-59$ & 46,051 & 787 & 853 & 171 & 159 & to & 183 & 0.92 & 0.86 & to & 0.99 \\
\hline M & $60-64$ & 33,729 & 339 & 379 & 101 & 90 & to & 112 & 0.89 & 0.81 & to & 0.99 \\
\hline M & $65-69$ & 24,066 & 65 & 61 & 27 & 21 & to & 34 & 1.06 & 0.83 & to & 1.37 \\
\hline$M$ & $70-74$ & 16,365 & 16 & 12 & 10 & 6 & to & 16 & 1.28 & 0.73 & to & 2.30 \\
\hline
\end{tabular}

Notes:

1. "Injury" defined as any diagnosis in the range ICD9:800-999.

2. Injuries occurring during the observation period 1987-Jan-01 to 2010-Dec-31.

3. Person-years is the sum of annual population counts during the observation period.

4. Observed number of injuries.

5. Expected number, indirectly standardized, based on age, gender and HSDA-specific rates in total population of BC

6. Crude Rate per 10,000 person-years.

7. Standardized Relative Risk (compared to the total population of $B C$ ) $=$ Observed/Expected.

risk: population per room, proportion of the population who identified themselves as Aboriginal, income score multiplied by employment, occupational risk multiplied by employment, proportion of university educated persons multiplied by employment, and Census year multiplied by employment. The entire model explained $32.5 \%$ of the variance among communities in SRR of worker compensation injury $\left(R^{2}=0.325, p<0.0005\right)$.

\section{Discussion}

It has been asserted that Aboriginal people in $\mathrm{BC}$ are at higher risk of injury than the total population, but our descriptive statistics offer a more varied perspective. In the category of worker compensation injury, Aboriginal people generally have lower risk. There are exceptions: in some HSDAs, and among women aged 50 years and older, Aboriginal people are at higher risk. Disparities in worker compensation injury risk might result from the competing effects of employment rates, occupations and industries. Aboriginal people have lower employment rates than the general population, but are more likely to work in hazardous occupations and industries. During the period 1987-2010, worker compensation injury rates declined for both the Aboriginal and the total populations, probably reflecting a secular trend towards safer work environments, but the decline was less among Aboriginal people. During the economic "boom" (measured in 2002 dollars, during the 5 years from 2002 to 2007, the Gross Domestic Product (GDP) of BC grew 19.0\%, a year-overyear average of $3.5 \%$ ), risk of worker compensation injury increased among Aboriginal people and went higher than the risk among the total population. In contrast, during 
Table 6 Worker compensation injuries [1], British Columbia, 1987-2010 [2], by Year

\begin{tabular}{|c|c|c|c|c|c|c|c|c|c|c|c|}
\hline \multirow{2}{*}{$\frac{\text { Year }}{1987}$} & \multirow{2}{*}{$\begin{array}{l}\text { P-years [3] } \\
3,121,318\end{array}$} & \multirow{2}{*}{$\begin{array}{l}\text { Obs [4] } \\
56,943\end{array}$} & \multirow{2}{*}{$\frac{\operatorname{Exp}[5]}{44,364}$} & \multirow{2}{*}{$\begin{array}{l}\text { Rate [6] } \\
182\end{array}$} & \multicolumn{3}{|c|}{$95 \% \mathrm{Cl}$ for Rate } & \multirow{2}{*}{$\begin{array}{l}\text { SRR [7] } \\
1.28\end{array}$} & \multicolumn{3}{|c|}{$95 \% \mathrm{Cl}$ for SRR } \\
\hline & & & & & 181 & to & 184 & & 1.27 & to & 1.30 \\
\hline 1988 & $3,165,022$ & 62,293 & 45,153 & 197 & 195 & to & 198 & 1.38 & 1.37 & to & 1.39 \\
\hline 1989 & $3,245,277$ & 68,314 & 46,509 & 211 & 209 & to & 212 & 1.47 & 1.46 & to & 1.48 \\
\hline 1990 & $3,339,763$ & 72,124 & 48,247 & 216 & 214 & to & 218 & 1.49 & 1.48 & to & 1.51 \\
\hline 1991 & $3,421,459$ & 67,786 & 49,492 & 198 & 197 & to & 200 & 1.37 & 1.36 & to & 1.38 \\
\hline 1992 & $3,515,345$ & 66,197 & 50,970 & 188 & 187 & to & 190 & 1.30 & 1.29 & to & 1.31 \\
\hline 1993 & $3,649,925$ & 64,624 & 53,506 & 177 & 176 & to & 178 & 1.21 & 1.20 & to & 1.22 \\
\hline 1994 & $3,771,519$ & 65,575 & 55,449 & 174 & 173 & to & 175 & 1.18 & 1.17 & to & 1.19 \\
\hline 1995 & $3,856,183$ & 61,873 & 56,649 & 160 & 159 & to & 162 & 1.09 & 1.08 & to & 1.10 \\
\hline 1996 & $3,959,300$ & 60,944 & 58,338 & 154 & 153 & to & 155 & 1.04 & 1.04 & to & 1.05 \\
\hline 1997 & $4,040,687$ & 58,697 & 59,628 & 145 & 144 & to & 146 & 0.98 & 0.98 & to & 0.99 \\
\hline 1998 & $4,087,714$ & 61,689 & 60,256 & 151 & 150 & to & 152 & 1.02 & 1.02 & to & 1.03 \\
\hline 1999 & $4,115,601$ & 49,584 & 60,640 & 120 & 119 & to & 122 & 0.82 & 0.81 & to & 0.82 \\
\hline 2000 & $4,114,815$ & 49,678 & 60,464 & 121 & 120 & to & 122 & 0.82 & 0.82 & to & 0.83 \\
\hline 2001 & $4,160,615$ & 58,317 & 61,161 & 140 & 139 & to & 141 & 0.95 & 0.95 & to & 0.96 \\
\hline 2002 & $4,211,443$ & 52,979 & 61,890 & 126 & 125 & to & 127 & 0.86 & 0.85 & to & 0.86 \\
\hline 2003 & $4,285,095$ & 50,983 & 63,310 & 119 & 118 & to & 120 & 0.81 & 0.80 & to & 0.81 \\
\hline 2004 & $4,335,962$ & 52,636 & 64,324 & 121 & 120 & to & 122 & 0.82 & 0.81 & to & 0.82 \\
\hline 2005 & $4,383,639$ & 55,255 & 65,001 & 126 & 125 & to & 127 & 0.85 & 0.84 & to & 0.86 \\
\hline 2006 & $4,414,528$ & 57,497 & 65,192 & 130 & 129 & to & 131 & 0.88 & 0.88 & to & 0.89 \\
\hline 2007 & $4,476,436$ & 58,476 & 66,025 & 131 & 130 & to & 132 & 0.89 & 0.88 & to & 0.89 \\
\hline 2008 & $4,546,001$ & 58,183 & 67,066 & 128 & 127 & to & 129 & 0.87 & 0.86 & to & 0.87 \\
\hline 2009 & $4,607,365$ & 45,298 & 67,875 & 98 & 97 & to & 99 & 0.67 & 0.66 & to & 0.67 \\
\hline 2010 & $4,632,154$ & 43,716 & 68,149 & 94 & 93 & to & 95 & 0.64 & 0.64 & to & 0.65 \\
\hline
\end{tabular}

Notes:

1. "Injury" defined as any diagnosis in the range ICD9:800-999.

2. Injuries occurring during the observation period 1987-Jan-01 to 2010-Dec-31.

3. Person-years is the population count during the specified year.

4. Observed number of injuries.

5. Expected number, indirectly standardized, based on age, gender and HSDA-specific rates in total population of BC during entire observation period.

6. Crude Rate per 10,000 person-years.

7. Standardized Relative Risk (compared to the total population of $B C$ during the entire observation period) $=$ Observed/Expected.

the subsequent economic "bust" (during the two years from 2007 to 2009, GDP shrank 1.7\%) [24], risk among Aboriginal people declined sharply to below the level of risk among the total population. As shown by our own analysis of Census data (see above), between the census years 2001 and 2006 the employment rate among Aboriginal reserve residents increased, and so did the hazardousness of their occupations. The jobs were insecure, because economic fluctuations were more severe in the industrial sectors where Aboriginal workers are concentrated. In "agriculture, forestry, fishing and hunting", measured in 2002 dollars, during the 5 years from 2002 to 2007, the GDP grew by $4.3 \%$, then in the subsequent two years from 2007 to 2009, GDP shrank disastrously by $16.2 \%$. During the same periods respectively, in "construction" the GDP grew by an astonishing $43.8 \%$ then shrank markedly by $5.3 \%[24]$.
Our ecological analysis of hypothesized socio-economic, work-related, and geographic risk markers demonstrates some interesting associations, and may provide clues regarding the web of causation surrounding risk of worker compensation injury among the Aboriginal population.

The best-fitting model indicated that increased household population per room, and increased proportion of the population who identified as Aboriginal were associated with decreased risk of injury. We are accustomed to associating crowded housing and Aboriginal ethnicity with socio-economic disadvantage. However, in a multivariable model (controlling for employment, occupation, income and education), population per room and Aboriginal identity may reflect family structure and cultural adherence, rather than disadvantaged economic conditions. It is plausible that living in communities where people value extended family relationships and have 
Table 7 Worker compensation injuries [1], Aboriginal BC, 1987-2010 [2], by Year

\begin{tabular}{|c|c|c|c|c|c|c|c|c|c|c|c|}
\hline \multirow{2}{*}{$\frac{\text { Year }}{1987}$} & \multirow{2}{*}{$\begin{array}{l}\text { P-years [3] } \\
96,252\end{array}$} & \multirow{2}{*}{$\begin{array}{l}\text { Obs [4] } \\
1,174\end{array}$} & \multirow{2}{*}{$\frac{\operatorname{Exp}[5]}{1,207}$} & \multirow{2}{*}{$\begin{array}{l}\text { Rate [6] } \\
122\end{array}$} & \multicolumn{3}{|c|}{$95 \% \mathrm{Cl}$ for Rate } & \multirow{2}{*}{$\begin{array}{l}\text { SRR [7] } \\
0.97\end{array}$} & \multicolumn{3}{|c|}{$95 \% \mathrm{Cl}$ for SRR } \\
\hline & & & & & 115 & to & 129 & & 0.92 & to & 1.03 \\
\hline 1988 & 99,507 & 1,336 & 1,266 & 134 & 127 & to & 142 & 1.06 & 1.00 & to & 1.11 \\
\hline 1989 & 102,607 & 1,567 & 1,327 & 153 & 145 & to & 160 & 1.18 & 1.12 & to & 1.25 \\
\hline 1990 & 104,866 & 1,639 & 1,381 & 156 & 149 & to & 164 & 1.19 & 1.13 & to & 1.25 \\
\hline 1991 & 108,471 & 1,564 & 1,437 & 144 & 137 & to & 151 & 1.09 & 1.03 & to & 1.15 \\
\hline 1992 & 111,758 & 1,499 & 1,489 & 134 & 128 & to & 141 & 1.01 & 0.96 & to & 1.06 \\
\hline 1993 & 116,061 & 1,560 & 1,558 & 134 & 128 & to & 141 & 1.00 & 0.95 & to & 1.05 \\
\hline 1994 & 119,614 & 1,609 & 1,608 & 135 & 128 & to & 141 & 1.00 & 0.95 & to & 1.05 \\
\hline 1995 & 122,026 & 1,416 & 1,640 & 116 & 110 & to & 122 & 0.86 & 0.82 & to & 0.91 \\
\hline 1996 & 124,891 & 1,365 & 1,681 & 109 & 104 & to & 115 & 0.81 & 0.77 & to & 0.85 \\
\hline 1997 & 126,909 & 1,488 & 1,704 & 117 & 111 & to & 123 & 0.87 & 0.83 & to & 0.92 \\
\hline 1998 & 128,332 & 1,478 & 1,718 & 115 & 109 & to & 121 & 0.86 & 0.82 & to & 0.90 \\
\hline 1999 & 128,945 & 1,318 & 1,720 & 102 & 97 & to & 108 & 0.77 & 0.73 & to & 0.80 \\
\hline 2000 & 130,683 & 1,243 & 1,732 & 95 & 90 & to & 101 & 0.72 & 0.68 & to & 0.75 \\
\hline 2001 & 133,025 & 1,457 & 1,755 & 110 & 104 & to & 115 & 0.83 & 0.79 & to & 0.87 \\
\hline 2002 & 135,727 & 1,446 & 1,781 & 107 & 101 & to & 112 & 0.81 & 0.78 & to & 0.85 \\
\hline 2003 & 139,955 & 1,370 & 1,845 & 98 & 93 & to & 103 & 0.74 & 0.71 & to & 0.78 \\
\hline 2004 & 142,881 & 1,485 & 1,877 & 104 & 99 & to & 109 & 0.79 & 0.76 & to & 0.83 \\
\hline 2005 & 145,834 & 1,687 & 1,907 & 116 & 110 & to & 121 & 0.88 & 0.85 & to & 0.92 \\
\hline 2006 & 148,458 & 1,759 & 1,932 & 118 & 113 & to & 124 & 0.91 & 0.87 & to & 0.95 \\
\hline 2007 & 151,609 & 2,023 & 1,964 & 133 & 128 & to & 139 & 1.03 & 0.99 & to & 1.08 \\
\hline 2008 & 154,876 & 1,769 & 1,993 & 114 & 109 & to & 120 & 0.89 & 0.85 & to & 0.93 \\
\hline 2009 & 158,252 & 1,265 & 2,030 & 80 & 76 & to & 84 & 0.62 & 0.60 & to & 0.65 \\
\hline 2010 & 159,482 & 1,219 & 2,055 & 76 & 72 & to & 81 & 0.59 & 0.57 & to & 0.62 \\
\hline
\end{tabular}

Notes:

1. "Injury" defined as any diagnosis in the range ICD9:800-999.

2. Injuries occurring during the observation period 1987-Jan-01 to 2010-Dec-31.

3. Person-years is the population count during the specified year.

4. Observed number of injuries.

5. Expected number, indirectly standardized, based on age, gender and HSDA-specific rates in total population of BC during entire observation period.

6. Crude Rate per 10,000 person-years.

7. Standardized Relative Risk (compared to the total population of BC during the entire observation period) $=$ Observed/Expected.

strong identification with Aboriginal heritage could have psychological benefits that lower the risk of injury among community members [5].

In the descriptive, individual-level analysis, we observed that among the Aboriginal population, urban residents were at higher risk of worker compensation injury than Aboriginal people who were not urban. But the ecologic analysis tested two geographic variables, "remoteness" and "environmental index" that were derived from distance to the nearest urban centre, and neither was independently associated with risk of worker compensation injury. This suggests that the higher risk among urban residents is due to intervention by one or some combination of the variables retained in the final model. Likely the variable was "employment", and it is plausible that urban dwelling Aboriginal people are more at risk for worker compensation injury because they are more likely to be employed.

The best-fitting model included the proportion of the population who were employed, but not as an independent variable with a directly proportional association with injury risk. Employment interacts multiplicatively with income, occupational risk, and university education. Increased occupational risk and increased employment, interacting together multiplicatively, are strongly associated with increased risk of worker compensation injury. Increased income and increased employment, interacting together multiplicatively, are strongly associated with decreased risk of worker compensation injury. These findings are plausible, as well as empirical. But it seems paradoxical that increased proportion of the population who are university-educated, and increased employment, 
Table 8 Ecological analysis of worker compensation injury risk among BC Aboriginal communities, 1999-2008, Regression [1] statistics from models with one independent $(X)$ variable

\begin{tabular}{|c|c|c|c|c|c|c|c|c|c|c|c|c|c|}
\hline X Variable & units & $\min$ & $\max$ & mean [2] & SD [2] & $\mathrm{N}$ & $R^{2}$ & B & SE & $\mathbf{P}$ & RR Ratio per SD [2] & L95CL & U95CL \\
\hline Census & 1 year & 2001 & 2006 & 2003.5 & 2.5 & 319 & 0.012 & 0.020 & 0.010 & 0.049 & 1.053 & 1.000 & 1.108 \\
\hline Income Per Capita 1000 & $\$ 1,000$ & 5.3 & 50.9 & 13.1 & 5.9 & 147 & 0.067 & 0.022 & 0.007 & 0.002 & 1.135 & 1.051 & 1.226 \\
\hline Income Score & 1 & 32.6 & 108.1 & 60.2 & 12.7 & 147 & 0.087 & 0.010 & 0.003 & 0.000 & 1.142 & 1.064 & 1.226 \\
\hline High School & $1 \%$ & 0.0 & 116.7 & 55.7 & 17.4 & 261 & 0.021 & 0.004 & 0.002 & 0.018 & 1.080 & 1.013 & 1.150 \\
\hline University Degree & $1 \%$ & 0.0 & 34.3 & 3.9 & 5.8 & 261 & 0.040 & 0.016 & 0.005 & 0.001 & 1.098 & 1.038 & 1.161 \\
\hline Pop Per Room & 1 & 0.30 & 1.11 & 0.53 & 0.11 & 260 & 0.069 & -1.294 & 0.296 & 0.000 & 0.866 & 0.811 & 0.924 \\
\hline Need Major Repairs & $1 \%$ & 0.0 & 120.0 & 32.7 & 19.2 & 261 & 0.005 & -0.002 & 0.002 & 0.267 & 0.963 & 0.900 & 1.030 \\
\hline Labour Force & $1 \%$ & 9.9 & 100.0 & 61.7 & 12.3 & 261 & 0.005 & -0.003 & 0.003 & 0.235 & 0.959 & 0.894 & 1.028 \\
\hline Employed & $1 \%$ & 7.7 & 77.3 & 47.3 & 11.0 & 261 & 0.027 & 0.008 & 0.003 & 0.008 & 1.094 & 1.024 & 1.169 \\
\hline Occupation Risk & $\mathrm{RR}$ & 0.00 & 2.71 & 1.12 & 0.36 & 261 & 0.008 & 0.148 & 0.105 & 0.159 & 1.054 & 0.979 & 1.135 \\
\hline Industry Risk & RR & 0.00 & 3.92 & 1.11 & 0.34 & 261 & 0.005 & 0.157 & 0.141 & 0.265 & 1.054 & 0.961 & 1.157 \\
\hline Remoteness & 1 & 0.08 & 1.35 & 0.23 & 0.22 & 317 & 0.008 & -0.183 & 0.113 & 0.108 & 0.961 & 0.916 & 1.009 \\
\hline Environ Index & 1 & 0.40 & 3.00 & 0.65 & 0.38 & 317 & 0.012 & -0.133 & 0.068 & 0.051 & 0.950 & 0.902 & 1.000 \\
\hline Aboriginal & $1 \%$ & 5.7 & 100.0 & 84.7 & 23.2 & 261 & 0.060 & -0.005 & 0.001 & 0.000 & 0.892 & 0.844 & 0.943 \\
\hline NAlndian & $1 \%$ & 5.6 & 103.1 & 81.5 & 23.8 & 261 & 0.054 & -0.005 & 0.001 & 0.000 & 0.896 & 0.847 & 0.948 \\
\hline
\end{tabular}

Notes:

1. The dependent $(\mathrm{Y})$ variable is Ln (SRR of worker compensation injury, total of all injuries), and regression is weighted by person-years.

2. Unweighted mean and standard deviation.

interacting together multiplicatively, are associated with increased risk of worker compensation injury. Perhaps this indicates that university-educated people can better access the worker compensation system. Alternatively, this may indicate that among Aboriginal people, having university education may lead to mismatching of educational level with job category, increasing the risk of worker compensation injury. Or, the paradox may be ecological: increased proportion with university education among the population may indicate a more unequal social order, with increased injury risk to those in the lower strata.

Time (as measured by Census year) and increased employment, interacting together multiplicatively, are

Table 9 Ecological analysis of worker compensation injury risk among BC Aboriginal communities, 1999-2008, Regression [1] statistics from models with one independent $(X)$ variable

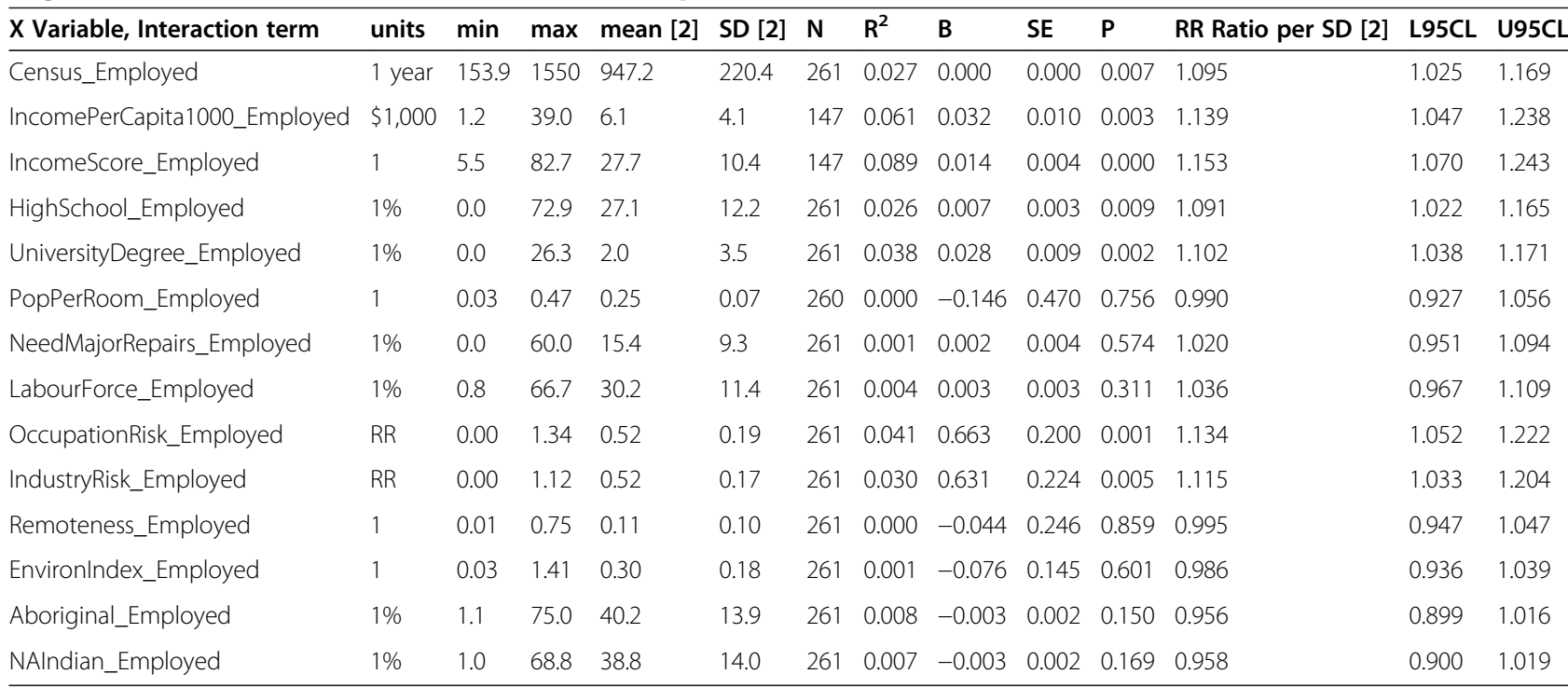


Table 10 Ecological analysis of worker compensation injury risk among BC Aboriginal communities, 1999-2008, Regression [1] statistics from the best-fitting model with multiple independent $(X)$ variables

\begin{tabular}{|c|c|c|c|c|c|c|c|c|c|c|c|c|}
\hline X Variable & units & $\min$ & $\max$ & mean [2] & SD [2] & $\mathrm{N}$ & B & SE & $\mathbf{P}$ & RR Ratio per SD [2] & L95CL & U95CL \\
\hline (Constant) & & & & & & 147 & 0.285 & 0.282 & 0.313 & & & \\
\hline PopPerRoom & 1 & 0.30 & 1.11 & 0.53 & 0.11 & 147 & -1.878 & 0.528 & 0.001 & 0.811 & 0.722 & 0.911 \\
\hline Aboriginal & $1 \%$ & 5.7 & 100.0 & 84.7 & 23.2 & 147 & -0.007 & 0.002 & 0.000 & 0.847 & 0.777 & 0.923 \\
\hline IncomeScore_Employed & 1 & 5.5 & 82.7 & 27.7 & 10.4 & 147 & -0.048 & 0.012 & 0.000 & 0.606 & 0.472 & 0.777 \\
\hline OccupationRisk_Employed & RR & 0.00 & 1.34 & 0.52 & 0.19 & 147 & 1.801 & 0.369 & 0.000 & 1.407 & 1.225 & 1.615 \\
\hline UniversityDegree_Employed & $1 \%$ & 0.0 & 26.3 & 2.0 & 3.5 & 147 & 0.050 & 0.014 & 0.001 & 1.189 & 1.077 & 1.313 \\
\hline Census_Employed & 1 year & 154 & 1550 & 947.2 & 220.4 & 147 & 0.002 & 0.000 & 0.002 & 1.395 & 1.133 & 1.717 \\
\hline
\end{tabular}

Notes:

Multivariable model statistics: $R^{2}=0.325, F=11.232, p=0.000$

1. The dependent $(Y)$ variable is Ln (SRR of worker compensation injury, total of all injuries), and regression is weighted by person-years.

2. Unweighted mean and standard deviation.

associated with increasing risk of worker compensation injury. This is disturbing, yet intriguing, as it suggests that among Aboriginal communities, there are other time-related factors that we have not measured, that are pushing worker compensation injury rates upwards, or preventing them from declining as much as injury rates in the total population.

Our ecological multivariable analysis studied only Aboriginal communities. We did not include any nonAboriginal communities. Therefore, the findings only apply to Aboriginal communities, and cannot be used to explain the observed differences in worker compensation injury rates between the Aboriginal and total populations of $\mathrm{BC}$. This matter invites future research, that includes both Aboriginal and non-Aboriginal communities in an ecological analysis.

\section{Data quality}

BC's universal health care insurance program is the best available registry of the province's population. Using this registry, in fiscal year 2006-2007 we counted 4,266,070 people in $\mathrm{BC}$, which is $103.7 \%$ of the number $(4,113,487)$ enumerated in $\mathrm{BC}$ by the 2006 Census of Canada. The slight excess may represent persons who were deceased or no longer resident in the province, but who had not yet been removed from the insurance registry.

Using the insurance registry and our definition of "Aboriginal" (derived from insurance premium group and notations on birth and death records), in fiscal year 2006-2007 we counted 148,458 people in $\mathrm{BC}$ whom we considered "Aboriginal", which is $75.8 \%$ of the number $(196,070)$ enumerated in $\mathrm{BC}$ who identified themselves as "an Aboriginal person, that is, North American Indian, Métis or Inuit (Eskimo)" in the 2006 Census of Canada. Our definition of "Aboriginal" is admittedly restrictive, and largely, if indirectly, based on legally recognized Indian status, as defined by the Indian Act of Canada. Some might say that we should have determined Aboriginality using the federal government's Indian Status Registry, but due to privacy issues and political considerations, it was not possible for us to get access to the Indian Status Registry. However, we consider our definition of "Aboriginal" to be superior to presence in the Indian Status Registry, because our definition includes residence in BC, whereas the Indian Status Registry reflects membership in a recognized First Nation or Indian band located in $\mathrm{BC}$, regardless of where the individual in fact resides. Also, our definition is more likely to include children who are eligible for Indian status because of their parents' Indian status, but who have not yet applied to be included in the Indian Status Registry.

We counted injuries registered for claims with the provincial worker compensation system. Work Safe BC's database is the reference standard. There is no better. We have confidence in its accuracy because compensation payments depend on this database, and people who do not get the payments to which they are entitled will take action to claim their due. Some may argue that limiting our analysis to injuries registered for worker compensation claims imposes an overly restrictive definition of occupational injury. However, limiting our definition helps to protect the internal validity of our analysis.

\section{Conclusions}

As an increasing proportion of Aboriginal people became employed with pay, over the past decade incidence of worker compensation injury among the Aboriginal population has reached parity with, or even exceeded that among the general population. We need culturally sensitive workplace injury prevention programming, particularly in geographic regions and industries where Aboriginal workers are concentrated. Targets for prevention programs should include older Aboriginal people, especially women. It is conventional wisdom that employment is good for health, but our analysis suggests the effects may be mixed. This challenge can be met with further knowledge and better-informed planning. 


\section{Abbreviations}

BC: British Columbia; GDP: Gross Domestic Product; HSDA: Health Service Delivery Area; MSP: Medical Services Plan of British Columbia;

SRR: Standardized Relative Risk

\section{Competing interests}

Andrew Jin, M. Anne George, Mariana Brussoni, and Christopher E. Lalonde declare that they have no competing interests.

\section{Authors' contributions}

AJ participated in the conception and design of the study, performed the statistical analysis and drafted the manuscript. MAG participated in the conception and design of the study and edited the manuscript. MB participated in the conception and design of the study and edited the manuscript. CEL participated in the conception and design of the study and edited the manuscript. All authors read and approved the final manuscript.

\section{Authors' information}

AJ is self-employed as an epidemiology consultant. MAG is an Associate Professor in the Department of Pediatrics, Faculty of Medicine, University of British Columbia, and Scientist Level 1 at the Child and Family Research Institute. MB is an Assistant Professor in the Department of Pediatrics, Faculty of Medicine, University of British Columbia, and Scientist Level 1 at the Child and Family Research Institute. CEL is a Professor in the Department of Psychology, Faculty of Social Sciences, University of Victoria.

\section{Acknowledgements}

This research was funded by the Canadian Institutes of Health Research (Funding reference: AHR \# 81043), by the British Columbia Region, First Nations and Inuit Health, Health Canada, and by the Child and Family Research Institute.

The authors thank Anna Low, Sherylyn Arabsky and Kelly Alke of Population Data BC for assistance with data access and linkage. The authors thank Dr. Rod McCormick for his contributions to the study design.

\section{Author details}

${ }^{1} 2762$ - 133 Street, Surrey, BC V4P 1X9, Canada. ${ }^{2}$ University of British Columbia and Child \& Family Research Institute, University of Northern BC, Room 9-387, 3333 University Way, Prince George, BC V2N 3Z9, Canada. ${ }^{3}$ University of British Columbia and Child \& Family Research Institute, Child and Family Research Institute, BC Children's Hospital, F511 - 4480 Oak Street, Vancouver, BC V6H 3 V4, Canada. ${ }^{4}$ Department of Psychology, University of Victoria, PO Box 1700, Victoria, BC V8W 2Y2, Canada.

Received: 19 November 2013 Accepted: 26 June 2014

Published: 10 July 2014

\section{References}

1. Bell N, Schuurman N, Hameed SM, Caron N: Are we homogenising risk factors for public health surveillance? Variability in severe injuries on First Nations reserves in British Columbia, 2001-5. Inj Prev 2011, 17:394-400.

2. British Columbia Vital Statistics Agency: Regional Analysis of Health Statistics for Status Indians in British Columbia, 1992-2002. Birth-Related and Mortality Statistics for British Columbia and 16 Health Service Delivery Areas. 2004. April 2004.

3. British Columbia, Provincial Health Officer: Pathways to Health and Healing 2nd Report on the Health and Well-being of Aboriginal People in British Columbia. Provincial Health Officer's Annual Report 2007. Victoria, BC: Ministry of Healthy Living and Sport; 2009 [http://www.health.gov.bc.ca/pho/pdf/ abohlth11-var7.pdf]

4. Bridges FS, Kunselman JC: Premature mortality due to suicide, homicide and motor vehicle accidents in health service delivery areas: comparison of status Indians in British Columbia, Canada with all other residents. Psychol Rep 2005, 97:739-749.

5. Chandler MJ, Lalonde C: Cultural continuity as a hedge against suicide in Canada's First Nations. Transcult Psychiatry 1998, 35(2):191-219.

6. Desapriya E, Sones M, Ramanzin T, Weinstein S, Scime G, Pike I: Injury prevention in child death review: child pedestrian fatalities. Inj Prev 2011, 17(Suppl 1):i4-i9. PubMed PMID: 21278097.

7. George MA, McCormick R, Jin A, Lalonde CE, Brussoni M: The RISC research project: injury in First Nations communities in British Columbia, Canada.
Int J Circumpolar Health 2013, 72:21182 [http://dx.doi.org/10.3402/ijch. v72i0.21182].

8. Breslin C, Koehoorn M, Smith P, Manno M: Age related differences in work injuries and permanent impairment: a comparison of workers' compensation claims among adolescents, young adults, and adults. Occup Environ Med 2003, 60(9):E10.

9. Mustard C, Cole D, Shannon H, Pole J, Sullivan T, Allingham R: Declining trends in work-related morbidity and disability, 1993-1998: a comparison of survey estimates and compensation insurance claims. Am J Public Health 2003, 93(8):1283-1286.

10. Fan J, McLeod CB, Koehoorn M: Descriptive epidemiology of serious workrelated injuries in British Columbia, Canada. Plos One 2012, 7(6):e38750

11. Alamgir H, Demers PA, Koehoorn M, Ostry A, Tompa E: Epidemiology of work-related injuries requiring hospitalization among sawmill workers in British Columbia, 1989-1997. Eur J Epidemiol 2007, 22(4):273-280.

12. Breslin FC, Smith P, Dunn JR: An ecological study of regional variation in work injuries among young workers. BMC Public Health 2007, 7:91.

13. Statistics Canada: Health Profile, Health Regions - British Columbia. [https:// www12.statcan.gc.ca/health-sante/82-228/search-recherche/lst/page.cfm? Lang=E\&GeoLevel=PR\&GEOCODE=59].

14. BC Stats: Census Profile for British Columbia Health Regions. 2011 [http:// www.bcstats.gov.bc.ca/StatisticsBySubject/Census/OpenData.aspx].

15. Agresti A, Coull BA: Approximate is better than 'exact' for interval estimation of binomial proportions. American Statistician 1998, 52:119-126.

16. Statistics Canada: 2005 Survey of Financial Security. Table 5-1: Quality level guidelines. [http://www.statcan.gc.ca/pub/13f0026m/2007001/table/ tab5p1-eng.htm]

17. Statistics Canada: General Social Survey - Data Quality Statements. [http:// www23.statcan.gc.ca/imdb-bmdi/document/3895_D1_T2_V1-eng.pdf].

18. Kahn HA, Sempos CT: Statistical Methods in Epidemiology. New York, Oxford: Oxford University Press; 1989:95-105.

19. Payton ME, Greenstone MH, Schenker N: Overlapping confidence intervals or standard error intervals: what do they mean in terms of statistical significance? J Insect Sci 2003, 3:34-39 [http://www.ncbi.nlm.nih.gov/pmc/ articles/PMC524673/]

20. Penney C, O'Sullivan E, Senécal S: The Community Well-Being Index (CWB): Examining Well-Being in Inuit Communities, 1981-2006. Aboriginal Affairs and Northern Development Canada: 2012 [http://www.aadnc-aandc.gc.ca/eng/ 1100100016579/1100100016580].

21. Table 1A: Claim Counts by Broad Group of the 1991 Standard Occupational Classification (SOC) and Year; Injury Years 2002-2011. [http://www.worksafebc. com/publications/reports/statistics_reports/occupational_injuries/2002-2011/ Table1A.pdf]. [http://www.worksafebc.com/publications/reports/ statistics_reports/occupational_injuries/2002-2011/default.asp]

22. Table B-1: An Analysis by Subsector of the 63,610 Short-term Disability, Long-term Disability, and Fatal Claims First Paid in 2006 and an Analysis of the Number of Days Lost During 2006 on Claims for All Years, Work Safe BC, 2006 Statistics. [http://www.worksafebc.com/publications/reports/ statistics_reports/assets/pdf/stats2006.pdf].

23. Corporate Information Management Directorate, Information Management Branch: Band Classification Manual. Aboriginal Affairs and Northern Development Canada; 2005 [http://publications.gc.ca/collections/Collection/ R22-1-2000E.pdf].

24. BC GDP by Industry - NAICS aggregations, 1997-2011, BC Stats: 2012 [http://www.bcstats.gov.bc.ca/Files/2c6af99c-2401-4a67-92d9-26aa8ceb2719/ BCGDPbylndustryChainedDollars.xIsx].

\section{doi:10.1186/1471-2458-14-710}

Cite this article as: Jin et al.: Worker compensation injuries among the Aboriginal population of British Columbia, Canada: incidence, annual trends, and ecological analysis of risk markers, 1987-2010. BMC Public Health 2014 14:710. 